Knowing the Enemy 



\section{Knowing the}

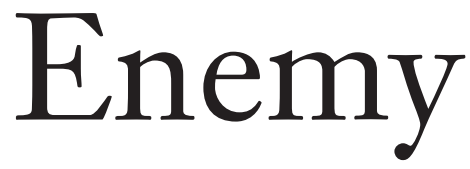

Fibadist Ideology and the War on Terror

\section{Mary R. Habeck}




\section{Copyright @ 2006 by Yale University.}

All rights reserved.

This book may not be reproduced, in whole or in part, including illustrations, in any form (beyond that copying permitted by Sections 107 and Io8 of the U.S. Copyright Law and except by reviewers for the public press), without written permission from the publishers.

Designed by Rebecca Gibb.

Set in Janson text type by Integrated Publishing Solutions.

Printed in the United States of America.

Library of Congress Cataloging-in-Publication Data

Habeck, Mary R.

Knowing the enemy : jihadist ideology and the War on Terror / Mary R. Habeck.

p. $\mathrm{cm}$.

Includes bibliographical references and index.

ISBN 0-300-I I 306-4 (hardcover : alk. paper)

I. Terrorism-Religious aspects-Islam. 2. Islam and world politics. 3. War on Terrorism, 200I-. I. Title.

$$
\begin{gathered}
\mathrm{BP}_{190.5} \cdot \mathrm{T}_{47} \mathrm{H}_{33} 2006 \\
297.2^{\prime}{ }^{2} \text { - } \mathrm{dc}_{22} \\
2005 \mathrm{OI} 52 \mathrm{IO}
\end{gathered}
$$

A catalogue record for this book is available from the British Library.

The paper in this book meets the guidelines for permanence and durability of the Committee on Production Guidelines for Book Longevity of the Council on Library Resources. 